\section{APROXIMACIONES AL ESTUDIO \\ DEL CONGRESO NACIONAL ARGENTINO. \\ CONTRASTES, CONVERGENCIAS Y \\ AGENDAS DE INVESTIGACIÓN}

DIFFERENT APPROACHES TO THE STUDY OF

ARGENTINE NATIONAL CONGRESS. CONTRASTS,

CONVERGENCES AND RESEARCH AGENDAS

VICTORIA ORTÍZ DE ROZAS •

Victoria Ortíz de Rozas es becaria post-doctoral del CONICET con sede en la Universidad Nacional de General Sarmiento (UNGS)

\section{Resumen}

El artículo revisa un conjunto de investigaciones sobre el Congreso Nacional argentino y sus integrantes, identificando perspectivas que incidieron en la agenda académica y áreas de vacancia. Se abordan los trabajos realizados por la ciencia política, interesada en el funcionamiento institucional del Congreso y en las carreras políticas de los legisladores. Luego se describen las investigaciones provenientes de la sociología política, focalizada en las variables sociales que inciden en el acceso de los legisladores al poder. Se señalan contrastes entre ambas perspectivas, argumentando que es posible establecer convergencias en términos de los referentes empíricos estudiados; obteniendo un cuadro más completo sobre las características de los legisladores nacionales y su reclutamiento. Teniendo en cuenta trabajos realizados en otros países, desde la antropología política y/o con métodos etnográficos, se propone una agenda de investigación que permitiría tener una visión más amplia sobre el rol de los legisladores y del Congreso como institución representativa.
Charcas 5028, PB $1^{\circ}$, Ciudad Autónoma de Buenos Aires.

E-mail: victoriaderozas@gmail.com

\section{Abstract}

The aim of the article is to analyse the researches which have the National Congress and their members in Argentina as an object of study, identifying perspectives and lines of research that have influenced the academic national agenda, and indicating vacancy areas. The article considers the researches coming from political science, interested in the institutional functioning of Congress as well as in legislators' political careers. Then, the article studies researches from the political sociology field, focused in the social variables that influence in the access of the legislators to power. There are contrasts among both perspectives, but it is argued that it is possible to establish empirical convergences; obtaining a more complete picture on national legislators and their recruitment. Taking into account researches in other countries, in the field of political anthropology, the article proposes a research agenda, with the aim of obtaining a wider vision on the role of legislators and Congress as a representative institution. 